\title{
TECHNOLOGY IN NEWS AND SPORTS PRODUCTION
}

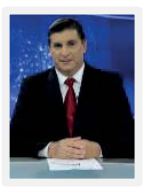

Moderador: Raimundo Lima

Chief Technical Officer (CTO) and Chief Operations Officer

(COO) at SBT / SET / FÓRUM BRASILEIRO DE TV DIGITAL

\section{Speaker: Carlos Nascimento}

Presenter - SBT

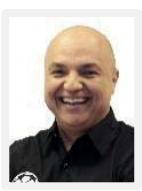

Speaker: André Henning

Commentator - EI - ESPORTE INTERATIVO

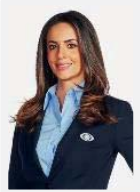

Speaker: Paloma Tocci

Presenter - BAND

Speaker: Eduardo Castro

Journalist \& Professor - Telezoom

Speaker: Representante da RECORD [convidado]

Speaker: Representante da TV GLOBO [convidado] 


\section{Content Production}

\section{TECHNOLOGY IN NEWS AND SPORTS PRODUCTION}

Moderator: Raimundo Lima

Chief Technical Officer (CTO) and Chief Operations Officer (COO) at SBT / SET / FÓRUM BRASILEIRO DE TV DIGITAL

Do início do processo de apuração, a captação e ao recebimento das notícias, as tecnologias da informação foram fortemente impactadas pela era das comunicações digitais.

O público, passou a ser parte integral do processo e o consumo das informações nas mais diversas plataformas, passou a ser a qualquer momento e em qualquer lugar.

- Speaker: Carlos Nascimento

Presenter - SBT

- Speaker: André Henning

Commentator - EI - ESPORTE INTERATIVO

- Speaker: Paloma Tocci

Presenter - BAND

- Speaker: Eduardo Castro

Journalist \& Professor - Telezoom

- Speaker: Representante da RECORD [convidado]

- Speaker: Representante da TV GLOBO [convidado]

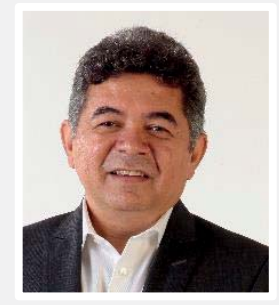

\section{RAIMUNDO LIMA}

Technical and Operations Director of SBT - SBT / SET/ BRAZILIAN DIGITAL TV FORUM With over 34 years' involvement in open television activities, he has held several positions and has spent time at Brazil's major television broadcasters: SBT - Executive Editor for Journalism and Technical and Operations Director. ESPORTE INTERATIVO - Production Director; TV CULTURA/SP - Operations Director; TV BAND - Head of Journalistic Production, Production Director, Operations and Technology Director; TV GLOBO / GINY - Editor and Producer; DIÁRIOS ASSOCIADOS/TV MANCHETE - Programs Director EDUCATIONAL BACKGROUND: UFF - Fluminense Federal University - Digital TV and New Electronic Media; PUC/SP - Multimedia Journalism; SONY INSTITUTE OF VIDEO TECHNOLOGY - Miscellaneous; UNB - University of Brasília - Education. 

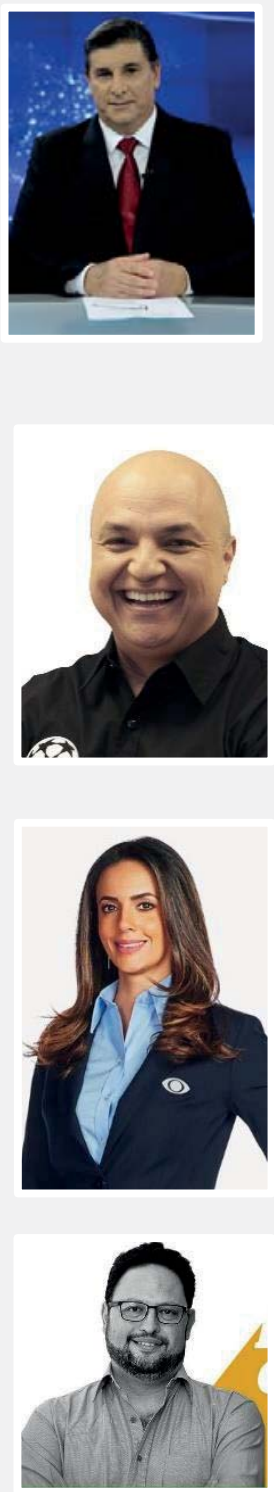

\section{CARLOS NASCIMENTO}

Presenter - SBT

Journalist known for covering relevant facts in Brazilian and world history. Began his career at RÁDIO CULTURA, worked for newspapers and started in television at TV GLOBO, where he worked for almost all the broadcaster's news programs. He made a name for himself covering the death of President Tancredo Neves, in 1985.

He has also worked at TV CULTURA, REDE RECORD, BAND and SBT. In 2005, working on the Band TV news program he won the Comunique-se Award as the best Brazilian TV presenter. He also received the Wladimir Herzog Award as a journalist in 1980 and 1981; the APCA Award in 1988 (TV Cultura News) and in 1989 (Record News).

\section{ANDRÉ HENNING}

Commentator - EI - ESPORTE INTERATIVO

For ten years he has been the channel's main reference in sporting and style broadcasts, with an emphasis on emotion. Before Esporte Interativo, André worked as a commentator and reporter for RÁDIO TRANSAMÉRICA and RÁDIO BANDEIRANTES, in São Paulo, and RÁDIO METRÓPOLE, in Salvador.

\section{PALOMA TOCCI}

Presenter - BAND

The journalist began her career at Band, making a name for herself in sport. She worked on the programs Jogo Aberto, Deu Olé, Band Esporte Clube and Café com Jornal and covered the Pan American Games in Rio de Janeiro, the Beijing Olympics, the Confederations Cup in South Africa, the 2014 World Cup and will cover the Rio Olympics. In January 2015, she began presenting the Band News Program alongside Ricardo Boechat

\section{EDUARDO CASTRO}

Journalist \& Professor - Telezoom

Holds a degree in Journalism from the Cásper Líbero School of Social Communication, São Paulo (1996). Read Law at the Paulista Law School (PUC-SP). Took courses in radio and tele journalism at VOA (Voice of America - USA) and NPR (National Public Radio - USA), and internships at CNN (Atlanta, 2004) and the BBC (London, 2006), specializing in editorial management, documentaries and extensive articles.Commentator on Esporte Interativo sports channel since February 2016. Column writer for the Fato On Line portal, writing about sports 2015/2016. He was president of the ACERP - Roquette-Pinto Association of Educational Communication - for a temporary term of office (90 days), when transferring from being supervisor of the SECOM Association to the MEC. He oversaw the activities of TV Escola, TV Ines - February to April 2015.Between 2011 and 2014 he was General manager of EBC Empresa Brasil de Comunicação, with responsibility for the areas of content and support for the public radio, TV and Web channel (TV Brasil, TV Brasil International, Rádio Nacional Brasília/Rio/Amazônia/Alto Solimões, Rádio MEC AM and FM, Agência Brasil and Portal EBC. During the same period, he held a seat on the Board of Directors of ACERP, was a full member of the National Cinema Council (MINC) and the Consultative Council on Digital Radio (MINICOM) - 2013/2014.In 2011, he provided consultancy at TV Miramar, a station that the Rede Record network runs in Mozambique, repositioning the station's journalism in terms of language, editing, texts, presentation, content, news program content and other journalism programs. In 2010 he was the EBC correspondent in Africa. He headed up the office set up in Maputo, Mozambique, and submitted articles for TV Brasil, Rádio Nacional and Agência Brasil.Between 2008 and 2010 he was Executive Manager for Journalism at EBC, supervising journalistic production at all the company's vehicles, implementing programs, interactivity and television and radio news programs.Prior to that, in 2007, he had been special advisor to Minister Franklin Martins, at the Social Communication Department of the Presidency of the Republic, working with the Executive Group that created public radio and television in Brazil, culminating in the creation of EBC. He worked for 13 years at the Bandeirantes Radio and Television Group in São Paulo, Brasilia and 
in The United States. He was a reporter, producer, editor and anchorperson and director of journalism at the Brasilia office. He worked for the Rede BAND network, Rádio Bandeirantes, BandNews FM, BandNews TV and Canal 21, having participated in implementing the latter. He was correspondent for two years in The United States, where he also worked at the Brazilian service of the Voice of America. He was also a stringer for Radio CNN en Español in Brasília. He has been in over 40 countries and 20 Brazilian states as special envoy.Prior to this, he had also worked at the radio stations Trianon, TV BAND, Bandnews TV and Canal 21. He was involved in major coverages, such as the September 11 attacks, the home kidnapping of the Japanese ambassador in Peru (1996), presidential travels to Arab countries, China, and others; the funerals of Pope Paul II (2005); the US elections in 2000 and 2004; the elections in Rwanda in 2010, the World Social Forum, Dakar/Senegal (2010), The World Cups in South Africa, Korea-Japan and France; and the Olympic Games in Athens, in addition to countless presidential trips on four continents. He gave talks at the Regional Forums of Public Radio in 2007 (Londrina-PR and Teresina-PI), the National Forum on Public Radio (Rio de Janeiro 2008), the International Encounter of Public Radio (Brasilia 2009), Encounter on Public TV Practices of Aracaju-SE (2008), at the Professional Journalists Trade Union of Belo Horizonte (2008), in addition to visiting countless schools and universities to participate in roundtables and debates, including at the Chamber of Deputies and the Federal Senate. He also trained professionals in Salvador (2006), Rio de Janeiro (2008), Brasília, (2008), Mozambique (2010) and Cape Verde (2010). He currently gives courses at Telezoom, in Rio de Janeiro. 